Vol.61: e18160159, 2018

http://dx.doi.org/10.1590/1678-4324-2018160159 ISSN 1678-4324 Online Edition
BRAZILIAN ARCHIVES OF BIOLOGY AND TECHNOLOGY

AN INTERNATIONAL JOURNAL

\title{
Modelling the growth of lactic acid bacteria at different temperatures
}

\author{
Ana Paula Rosa da Silva ${ }^{1}$, Daniel Angelo Longhi ${ }^{1,2}$, Francieli Dalcanton ${ }^{3}$, Gláucia Maria \\ Falcão de Aragão ${ }^{1 *}$, \\ ${ }^{1}$ Universidade Federal de Santa Catarina - Departamento de Engenharia Química e Engenharia de Alimentos, \\ Florianópolis, Santa Catarina, Brasil, ${ }^{2}$ Universidade Federal do Paraná - Campus Jandaia do Sul, Jandaia do Sul, \\ Paraná Brasil; ${ }^{3}$ Univerisidade Comunitária da Região de Chapecó-Área de Ciências Exatas e Ambientais, Chapecó, \\ Santa Catariana, Brasil.
}

\begin{abstract}
Mathematical models are widely used to predict the shelf life of foods. Lactic acid bacteria (LAB), particularly Lactobacillus plantarum, Weissella viridescens and Lactobacillus sakei, are the main spoilage bacteria of refrigerated, vacuum-packed meat products, stored in modified atmosphere, and their growth determines the shelf life length of these products. The objective of this study was to model the growth of $\underline{L}$. plantarum, $\underline{W}$. viridescens and $\underline{L}$. sakei under different isothermal cultivation conditions and establish secondary models to describe the effect of temperature on the growth parameters of these bacteria. The LAB growth was evaluated in culture medium at temperatures of 4, 8, 12, 16, 20 and $30{ }^{\circ} \mathrm{C}$. The fit of Baranyi and Roberts (BAR) and Gompertz (GO) primary models to the growth curves of LAB was compared by statistical indices, in which the $B A R$ model showed slightly better fits to the experimental data. The BAR growth parameters were used to establish the secondary models, $\mu$ max and $N_{\text {max }}$ were established for the three $L A B$. The power model described the influence of temperature on the parameter $\lambda$ for $\underline{L}$. plantarum, and other bacteria showed no lag phase. The growth of LAB was strongly influenced by storage temperature and the obtained models allow predicting the growth of these bacteria within the temperature range from 4 to $30^{\circ} \mathrm{C}$.
\end{abstract}

Key words: predictive microbiology, shelf life, bacterial spoilage.

\footnotetext{
*Author for correspondence: gmf.aragao@gmail.com, glaucia.aragao@ufsc.br
} 


\section{INTRODUCTION}

Lactic acid bacteria (LAB) are considered the main microorganisms responsible for spoilage of vacuum-packed meat products stored under refrigerated conditions ${ }^{1,2}$, and some bacteria of the genus Lactobacillus are found naturally on meat and meat products, e.g. Lactobacillus sakei, Weissella viridescens, Lactobacillus plantarum and Lactobacillus curvatus ${ }^{3,4}$. The deterioration caused by the LAB is related to the production of metabolites that cause undesirable changes in appearance, texture and flavor of the food, producing unpleasant odors and flavors, besides producing slime on the products' surface ${ }^{5,6,7}$.

Meat products have an initial concentration of LAB normally around $10 \mathrm{CFU} / \mathrm{g}$ and this concentration often reaches a population of $10^{8}$ to $10^{9} \mathrm{CFU} / \mathrm{g}$ in the stationary phase of bacterial growth, exceeding the microbiological limit to the end of the shelf life of refrigerated meat, which is $10^{7} \mathrm{CFU} / \mathrm{g}^{1,8}$. Mathematical modeling can be used to predict the effect of different combinations of time and temperature on the shelf life of meat products. The modeling of microbial growth in culture medium introduces factors that can be controlled more easily than food matrices ${ }^{9}$.

Changes in $\mathrm{pH}$ may also be associated with spoilage of meat products. The lactic acid produced by $\mathrm{LAB}$ during growth can reduce the $\mathrm{pH}$ of the medium where bacteria are growing. Manios et al. ${ }^{10}$ found, by means of high performance liquid chromatography analysis that lactic acid production is primarily responsible for the increased acidity of acid emulsions containing pepper, eggplant and fava beans, caused by L. plantarum and L. brevis.

There is a large amount and variety of predictive models that can describe isothermal microbial growth curves ${ }^{11,12}$. Two of the several types of models used are the model of Gompertz ${ }^{13}$ and the model of Baranyi and Roberts ${ }^{14}$. These primary models are currently applied often in assessing the growth of different microorganisms ${ }^{2,15,16,17}$.

Secondary models describe microbial behavior according to the variation of intrinsic and extrinsic factors. The influence of temperature on the microbial growth of LAB can be described by some of these models, e.g. linear equation, square root equation ${ }^{18}$, Arrhenius equation, power equation and exponential equation.

The objective of this study was to model the growth of L. plantarum, W. viridescens and $L$. sakei under isothermal cultivation conditions and establish secondary models describing the effect of temperature on growth parameters: duration of the lag phase $(\lambda)$, maximum specific growth rate $\left(\mu_{\max }\right)$, maximum bacterial population $\left(N_{\max }\right)$ and time to reach $10^{7} \mathrm{CFU} / \mathrm{mL}\left(t_{7}\right)$, while considering the concentration of $\mathrm{LAB}$ that defines the shelf life of meat products.

\section{MATERIAL AND METHODS}

\section{Bacteria}

The strains of Lactobacillus plantarum (CCT 0580 ATCC 8014), Weissella viridescens (CCT 5843 ATCC 12706) and Lactobacillus sakei (CCT 5841 ATCC 15521) were purchased from André Tosello Foundation of Tropical Cultures (Campinas, Brazil) and stored in polypropylene tubes at the temperature of $-24{ }^{\circ} \mathrm{C}$ in MRS broth (Man, Rogosa and Sharpe) (Difco, Le Pont de Claix, France) containing $20 \%$ (v/v) glycerol for later use.

\section{Inoculum Preparation}

For each LAB, the strain frozen was reactivated in MRS broth at $30{ }^{\circ} \mathrm{C}$ in an incubator (Dist, Florianópolis, Brazil) for $18 \mathrm{~h}$. After, viable cell count was performed with the plating technique on bilayer MRS agar medium in sterile disposable petri plates, incubated at $30{ }^{\circ} \mathrm{C}$ for $48 \mathrm{~h}$. The count was expressed in CFU/mL. In all experiments 
performed, the three $\mathrm{LAB}$ had the maximum cell concentration of $10^{9} \mathrm{CFU} / \mathrm{mL}$, after incubation for $18 \mathrm{~h}$, which was then treated as the inoculum condition for the other experiments.

\section{Growth Conditions}

The experiments with pure $\mathrm{LAB}$ cultures were carried out in $250 \mathrm{~mL}$ flasks with a volume of $160 \mathrm{~mL}$ MRS broth and $1 \%$ (v/v) inoculum. The initial concentration of experiments was approximately $10^{3} \mathrm{CFU} / \mathrm{mL}$ and initial $\mathrm{pH}$ was $6.0(\mathrm{pH}$ meter V620, Analion, Ribeirão Preto, Brazil). The flasks were incubated at six different temperatures: $4,8,12,16,20$ and $30^{\circ} \mathrm{C}$, and growth curves were observed until the stationary phase. This procedure was performed for each of the LAB. The experiments were repeated on different days, thus generating duplicate experiments, and each experiment was carried out daily with duplicate Erlenmeyer flasks. The incubation temperature was recorded by a data logger (Testo 174, Lenzkirch, Germany) with records generated every 5 minutes.

The increase in cell concentration was monitored by counting viable cells by the plating method as described above, and also by measuring absorbance (abs) in a spectrophotometer (Bel Photonics 1105, Monza, Italy) at a wavelength of $600 \mathrm{~nm}$, at predetermined time intervals, depending on the temperature of incubation. As soon as $a b s$ measurement began to detect growth, plating was no longer performed on the samples, and a correlation model was used for each LAB, as described below. $\mathrm{pH}$ was monitored for each LAB at the six temperatures.

\section{Correlation Model}

Equations (1), (2) and (3) represent the correlations between viable cell count $(N)$ and absorbance measurements $(a b s)$, as previously defined, with $R^{2}$ values of $0.936,0.949$ and 0.935 for $L$. plantarum, W. viridescens and $L$. sakei, respectively.

$$
\begin{aligned}
& \ln N=1.715(\ln a b s)+18.82 \\
& \ln N=1.274(\ln a b s)+20.08 \\
& \ln N=1.478(\ln a b s)+19.79
\end{aligned}
$$

\section{Primary Growth Models}

The primary models of Baranyi and Roberts (BAR) and Gompertz (GO) were selected to describe the growth of $\mathrm{LAB}$ at the six incubation temperatures.

The primary model of Baranyi and Roberts ${ }^{14}$ is shown in Equations (4) and (5), in which $\ln N(t)$ is the natural logarithm of viable cell count [CFU/mL] at time $t, A(t)$ is an adjustment function, and the growth parameters are maximum specific growth rate $\left(\mu_{\max }[1 / \mathrm{h}]\right)$, initial and maximum bacterial population $\left(N_{o}[\mathrm{CFU} / \mathrm{mL}]\right.$ and $N_{\max }$ $[\mathrm{CFU} / \mathrm{mL}]$, respectively), and physiological state of cells $\left(h_{0}\right)$. The duration of the lag phase $(\lambda[\mathrm{h}])$ can be obtained by Equation (6).

$$
\begin{aligned}
& \operatorname{In}(\mathrm{N}(\mathrm{t}))=\operatorname{In}\left(N_{0}\right)+\mu_{\max } A(t)-\ln \left(1+\frac{e^{\mu_{\max }}-1}{e^{\left(\ln \left(N_{\max }\right)-\ln \left(N_{0}\right)\right)}}\right) \\
& A(t)=t+\frac{1}{\mu_{\max }} \ln \left(e^{\left(-\mu_{\max } t\right)}+e^{-h_{0}}-e^{\left(\left(-\mu_{\max } t\right)-h_{0}\right)}\right)
\end{aligned}
$$




$$
\lambda=\frac{h_{0}}{\mu_{\max }}
$$

The primary model of Gompertz ${ }^{13}$ is shown in Equation (7), in which $\ln N(t)$ is the natural logarithm of viable cell count $[\mathrm{CFU} / \mathrm{mL}]$ at time $t, C$ is an empirical parameter equivalent to the natural logarithm of initial microbial count, $A$ is the logarithmic amplitude of the population growth, $B$ is the relative maximum growth rate at time $M$ [1/h] and $M$ is the time required to achieve maximum growth rate [h]. The maximum specific growth rate $\left(\mu_{\max }\right)$ and duration of the lag phase $(\lambda)$ can be obtained by Equations (8) and (9).

$$
\begin{aligned}
& \ln (N(t))=\mathrm{C}+\mathrm{Aexp}\{-\exp [-B(t-M)]\} \\
& \mu_{\text {max }}=\frac{A B}{e} \\
& \lambda=M-\frac{1}{B}
\end{aligned}
$$

Primary models were fitted to the experimental data using the software MATLAB R2010a, version 7.10 (Mathworks, Natick, USA).

\section{Secondary Models}

Five mathematical equations were assessed as secondary models: linear equation, square root equation, Arrhenius equation, power equation and exponential equation, shown in Equations (10) to (14), respectively. All these secondary models are able to describe the dependence of model parameters up to the optimum growth rate (suboptimal temperature range). In these equations, $p$ is the parameter of interest to be modeled $\left(\lambda, \mu_{\max }, N_{\max }\right.$ or $t_{7}$ (time to reach $\left.10^{7} \log \mathrm{CFU} / \mathrm{mL}\right), T$ is the temperature $\left({ }^{\circ} \mathrm{C}\right.$ ), $T_{\min }$ is the theoretical minimal temperature for microbial growth $\left({ }^{\circ} \mathrm{C}\right), a$ and $b$ are empirical parameters.

Secondary models were fitted to the data using the software MATLAB R2010a, version 7.10 (Mathworks, Natick, USA)

$$
\begin{aligned}
& p=b+a T \\
& \sqrt{p}=b\left(T-T_{\text {min }}\right) \\
& \ln p=a\left(\frac{1}{T}\right)+b \\
& p=b T^{a} \\
& p=a \exp (b T)
\end{aligned}
$$

\section{Statistical Comparison of the Models}

To compare the fitting of the primary and secondary models to the experimental data, the following statistical indices were used: coefficient of determination $\left(R^{2}\right)$, mean squared error (MSE) and accuracy factor ${ }^{19}$. 


\section{RESULTS AND DISCUSSION}

\section{Primary Models}

According to the analysis of statistical indices (MSE, $R^{2}$ and accuracy factor), the two primary models assessed (BAR and GO) presented a good fit to the growth curves of the bacterial species. For L. plantarum, MSE values ranged from 0.073 to 0.286 and from 0.152 to $0.296 ; R^{2}$ values ranged from 0.983 to 0.998 and from 0.980 to 0.995 , and the values of the accuracy factor ranged from 1.012 to 1.030 and from 1.019 to 1.034 for the models of BAR and GO, respectively. For W. viridescens, MSE values ranged from 0.109 to 0.218 and from 0.050 to $0.207 ; R^{2}$ values ranged from 0.995 to 0.997 and from 0.992 to 0.998 , and the values of the accuracy factor ranged from 1.012 to 1.023 and from 1.010 to 1.021 for the models of BAR and GO, respectively. For $L$. sakei, MSE values ranged from 0.070 to 0.443 and from 0.091 to $0.411 ; R^{2}$ values ranged from 0.986 to 0.997 and from 0.987 to 0.997 , and the values of the accuracy factor ranged from 1.011 to 1.026 and from 1.010 to 1.025 for the models of BAR and $\mathrm{GO}$, respectively.

The values of statistical indices of the BAR model for L. plantarum, W. viridescens and $L$. sakei were slightly better than the values of the GO model, as previously observed ${ }^{20}$. Thus, the BAR model was chosen to define the growth parameters of the three LAB (Table 1) and to obtain the secondary models. Figure 1 shows the fits of BAR model to the growth curves. For ease of viewing, each temperature was represented by only one curve for each experiment.

Table 1. Growth parameters $\mu_{\max }(1 / \mathrm{h}), \lambda(\mathrm{h})$ and $\ln N_{\max }$ obtained by fitting the BAR model for $L$. plantarum, $W$. viridescens and $L$. sakei at different cultivation temperatures

\begin{tabular}{|c|c|c|c|c|c|c|c|c|c|}
\hline & \multicolumn{3}{|c|}{ L. plantarum } & \multicolumn{3}{|c|}{ W. viridescens } & \multicolumn{3}{|c|}{ L. sakei } \\
\hline & $\lambda$ & $\boldsymbol{\mu}_{\max }$ & $\ln N_{\max }$ & $\lambda$ & $\boldsymbol{\mu}_{\max }$ & $\ln N_{\max }$ & $\lambda$ & $\boldsymbol{\mu}_{\max }$ & $\ln N_{\max }$ \\
\hline $30^{\circ} \mathrm{C}$ & 0.3 & 0.65 & 22.7 & 0.0 & 0.78 & 21.9 & 0.0 & 0.78 & 21.9 \\
\hline $20{ }^{\circ} \mathrm{C}$ & 2.0 & 0.30 & 22.5 & 0.0 & 0.43 & 21.9 & 0.0 & 0.34 & 21.9 \\
\hline $16{ }^{\circ} \mathrm{C}$ & 3.7 & 0.16 & 21.9 & 0.0 & 0.25 & 21.8 & 0.0 & 0.24 & 21.7 \\
\hline $12{ }^{\circ} \mathrm{C}$ & 12.0 & 0.06 & 22.2 & 0.0 & 0.16 & 21.4 & 0.0 & 0.17 & 21.2 \\
\hline $8^{\circ} \mathbf{C}$ & 127.9 & 0.01 & 16.9 & 0.0 & 0.06 & 20.9 & 0.0 & 0.06 & 20.2 \\
\hline $4^{\circ} \mathrm{C}$ & $\mathrm{NG}^{*}$ & $\mathrm{NG}^{*}$ & $\mathrm{NG}^{*}$ & 0.0 & 0.02 & 19.4 & 0.0 & 0.02 & 19.5 \\
\hline
\end{tabular}

Duration of the lag phase and maximum specific growth rate are strongly influenced by temperature of incubation (Table 1 and Figure 1). With decreasing temperature, there is an increase of lag phase only for L. plantarum. The other two bacteria did not show adaptation phase in any of the tested temperatures. There was a decrease in the maximum specific growth rate with the decrease in the incubation temperature. This trend was observed by other authors, who also found that growth parameters of LAB are influenced by varying the growth temperature ${ }^{1,2,21}$.

There was no growth of $L$. plantarum at $4{ }^{\circ} \mathrm{C}$ (Table 1). Dalcanton ${ }^{21}$ also found that $L$. plantarum showed no growth at $4{ }^{\circ} \mathrm{C}$ for six months, when evaluating the combined effect of temperature, $\mathrm{pH}$, sodium chloride and sodium lactate in the growth of this LAB. Manios et al. ${ }^{10}$ studied the spoilage of acidic emulsified spreads containing pepper, eggplant and fava beans, caused by L. plantarum and L. brevis, and they observed that the LAB showed no growth in the emulsions at $4{ }^{\circ} \mathrm{C}$.

The most important parameters for the analysis of shelf life of meat products are lag phase and maximum specific growth rate ${ }^{22}$. However, control of maximum population can also lead to increased shelf life of the contaminated products. Cayré et al. ${ }^{23}$, when evaluating the effect of storage temperature $\left(0,8\right.$ and $\left.15^{\circ} \mathrm{C}\right)$ on the growth of LAB in meat sausages packed in different oxygen permeability, reported an absence of the lag 
phase in the growth curves fitted by the modified Gompertz model. Geitenes et al. ${ }^{22}$ noted the absence of the lag phase while modeling the growth of LAB in sliced cooked and vacuum packaged ham and formed ham samples at $5{ }^{\circ} \mathrm{C}$. The curves were fitted by the modified Gompertz and Logistic models, and the samples already had high counts on the first day of shelf life.

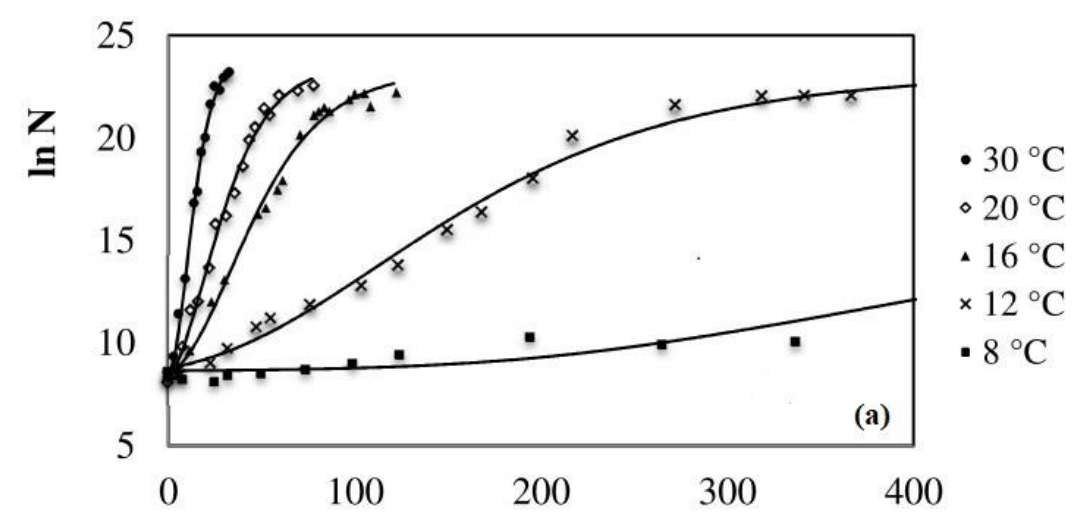

Time (h)

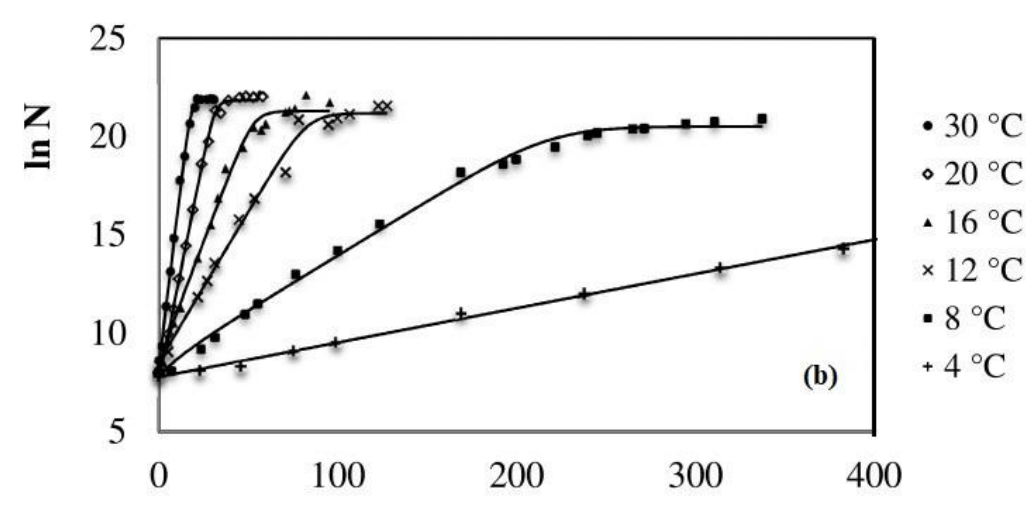

Time (h)

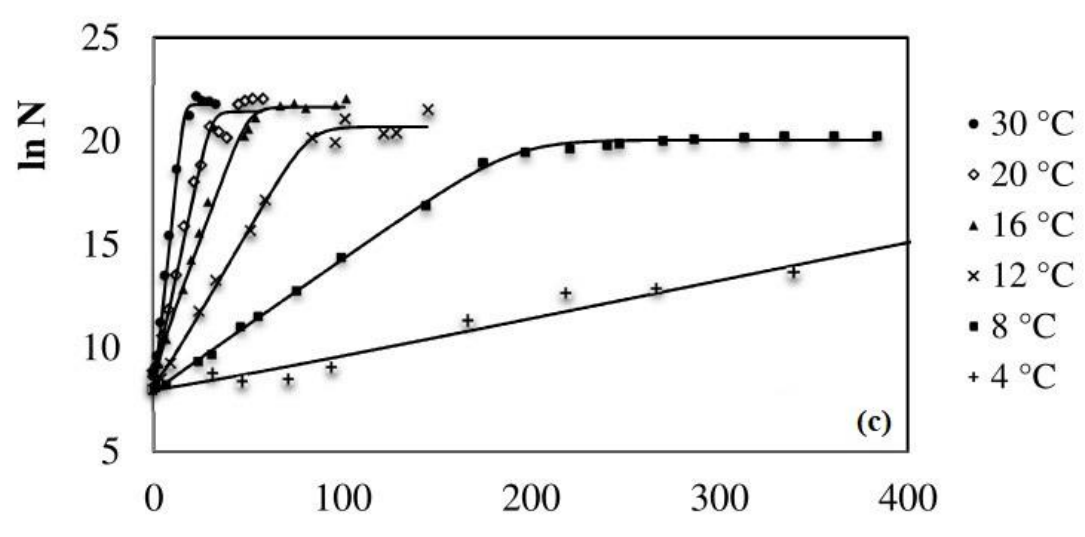

Time (h)

Figure 1. Fitting of the BAR model (solid line) to the experimental data (symbols) of the growth curves of (a) $L$. plantarum, (b) W. viridescens and (c) L. sakei at different temperatures. 
The results in Table 1 and Figure 1 show that it is crucial to maintain incubation temperatures below $8{ }^{\circ} \mathrm{C}$ to reduce the growth of LAB. The values of the maximum population at 4 and $8{ }^{\circ} \mathrm{C}$ were lower when compared with the other incubation temperatures. This shows that the increase in temperature directly influences the growth of $\mathrm{LAB}$. As meat products are typically stored in a temperature range between $4{ }^{\circ} \mathrm{C}$ and $10{ }^{\circ} \mathrm{C}$, it is strongly recommendable that this variable has to be controlled. The increase in the incubation temperature from 8 to $12{ }^{\circ} \mathrm{C}$ increases the maximum specific growth rate of LAB by more than $77 \%, 60 \%$ and $64 \%$ for L. plantarum, W. viridescens and L. sakei, respectively. These small increases in temperature (ranging from $4{ }^{\circ} \mathrm{C}$ to 30 ${ }^{\circ} \mathrm{C}$ ) cause changes in all growth parameters, as shown in Figure 1. Thus, in order to control the development and multiplication of spoilage bacteria, such as LAB in meat products that are vacuum-packaged or stored in modified atmosphere, it is crucial to control the temperature in the cold chain.

\section{Secondary Models}

The influence of incubation temperature $\left(4\right.$ to $\left.30^{\circ} \mathrm{C}\right)$ on growth parameters, obtained by fitting the BAR model, was described by comparing $\left(R^{2}\right)$ of the fits of the Linear, Square Root, Arrhenius, Power and Exponential equations to the experimental data. Table 2 shows the secondary models that best described such influence for all three bacteria.

Table 2. Equations of secondary models that best described the influence of temperature on the growth parameters $\mu_{\max }(1 / \mathrm{h}), \lambda(\mathrm{h}), N_{\max }(\mathrm{CFU} / \mathrm{mL})$ and $t_{7}$ (hours) of L. plantarum, W. viridescens and L. sakei.

\begin{tabular}{ccccc}
\hline Microorganism & Parameter & Equation & $\mathbf{R}^{2}$ & Model \\
\hline \multirow{4}{*}{ L. plantarum } & $\lambda$ & $\lambda=10^{6}\left(T^{-4.517}\right)$ & 0.989 & Power \\
& $\boldsymbol{\mu}_{\max }$ & $\sqrt{\mu_{\max }}=0.031 T-0.127$ & 0.992 & Square root \\
& $\mathbf{N}_{\max }$ & In $N_{\max }=-3.166\left(\frac{1}{T}\right)+3.273$ & 0.786 & Arrhenius \\
& $\mathbf{t}_{7}$ & $t_{7}=285,335\left(T^{-3.023}\right)$ & 0.975 & Power \\
\hline \multirow{2}{*}{ W. viridescens } & $\boldsymbol{\mu}_{\max }$ & $\sqrt{\mu_{\max }}=0.028 T+0.038$ & 0.993 & Square root \\
& $\mathbf{N}_{\max }$ & In $N_{\max }=-0.591\left(\frac{1}{T}\right)+3.112$ & 0.991 & Arrhenius \\
& $\mathbf{t}_{7}$ & $t_{7}=9,502\left(T^{-2.021}\right)$ & 0.989 & Power \\
\hline \multirow{2}{*}{ L. sakei } & $\boldsymbol{\mu}_{\max }$ & $\sqrt{\mu_{\max }}=0.028 T+0.037$ & 0.993 & Square root \\
& $\mathbf{N}_{\max }$ & In $N_{\max }=-0.581\left(\frac{1}{T}\right)+3.105$ & 0.923 & Arrhenius \\
& $\mathbf{t}_{7}$ & $t_{7}=6,159\left(T^{-1.864}\right)$ & 0.990 & Power \\
\hline
\end{tabular}

The equations fitted well to the data, resulting in good determination coefficients, as can be seen in Table 2 . The growth parameters of L. plantarum, W. viridescens and $L$. sakei can be predicted using the equations in Table 2 within the temperature range considered in this study $\left(4{ }^{\circ} \mathrm{C}\right.$ to $\left.30^{\circ} \mathrm{C}\right)$.

The parameters of microbial growth (duration of the lag phase and maximum specific growth rate) are associated with the shelf life of foods ${ }^{16,24,25}$. Any change in these growth parameters, caused by variation in the incubation temperature, will interfere in 
determining shelf life, or in determining the time needed to reach the LAB concentration of $10^{7} \mathrm{CFU} / \mathrm{mL}\left(t_{7}\right)$.

The microbiological limit for LAB that has been verified as the end of the shelf life of refrigerated meat products (depending on the organism, the food, and the individual preferences of the consumer) is $10^{7} \mathrm{CFU} / \mathrm{g}{ }^{1,4}$. The time needed to reach the $\mathrm{LAB}$ concentration of $10^{7} \mathrm{CFU} / \mathrm{mL}\left(t_{7}\right)$ estimated by the BAR model to the growth curves of $L$. plantarum, W. viridescens and L. sakei are shown in Table 3. According to the analysis of the values obtained for the $t_{7}$ of each $\mathrm{LAB}$, the abuse of temperature contributes to the development and proliferation of LAB, which are the major spoilage bacteria of meat and meat products that are vacuum-packed or stored in modified atmosphere. Again, these results show ones that it is strongly recommendable the control of refrigeration temperature.

Table 3. Time (in hours) needed to reach the LAB concentration of $10^{7} \mathrm{CFU} / \mathrm{mL}$ estimated by the BAR model to the growth curves of L. plantarum, W. viridescens and L. sakei.

\begin{tabular}{lrrr}
\hline & L. plantarum & W. viridescens & L. sakei \\
\hline $\mathbf{3 0}{ }^{\circ} \mathbf{C}$ & 13 & 12 & 13 \\
$\mathbf{2 0}^{\circ} \mathbf{C}$ & 27 & 22 & 21 \\
$\mathbf{1 6}{ }^{\circ} \mathbf{C}$ & 53 & 31 & 31 \\
$\mathbf{1 2}^{\circ} \mathbf{C}$ & 140 & 51 & 53 \\
$\mathbf{8}^{\circ} \mathbf{C}$ & 673 & 144 & 146 \\
$\mathbf{4}^{\circ} \mathbf{C}$ & $\mathrm{NG}^{*}$ & 653 & 476 \\
\hline$* \mathrm{NG}=$ & & &
\end{tabular}

Spoilage of meat products is analyzed by comparing sensory evaluation with microbial growth. Foods often reach the end of shelf life ( $7 \mathrm{log}$ CFU/g) showing strong signs of sensory spoilage ${ }^{26}$. Dalcanton et $\mathrm{al}^{4}{ }^{4}$ observed delayed sensory changes of vacuumpacked chopped cooked pork for the three incubation temperatures $\left(4,10\right.$ and $\left.16^{\circ} \mathrm{C}\right)$. They found that spoilage progresses slowly and starts when the cell concentration of $L$. plantarum is above $7 \log \mathrm{CFU} / \mathrm{g}$ for incubation temperatures of 10 and $16^{\circ} \mathrm{C}$, because at the temperature of $4{ }^{\circ} \mathrm{C}$, the maximum population attained was $5.25 \log \mathrm{CFU} / \mathrm{g}$.

\section{pH of LAB}

In Figure 2, there was a decrease in $\mathrm{pH}$ values, i.e., an increase of lactic acid concentration when the cell concentration of $L$. plantarum reached values of $7 \mathrm{log}$ $\mathrm{CFU} / \mathrm{mL}$ for the temperatures of $30,20,16$ and $12^{\circ} \mathrm{C}$, and for $8{ }^{\circ} \mathrm{C}$, cell concentration was $6 \log \mathrm{CFU} / \mathrm{mL}$. For $W$. viridescens and $L$. sakei, $\mathrm{pH}$ values started to decrease when cell concentration reached values of $8 \log \mathrm{CFU} / \mathrm{mL}$.

These differences between decrease in $\mathrm{pH}$ and cell concentration reached by $\mathrm{LAB}$ are because these bacteria belong to different species, thus producing different results. Similar results were also observed by Ruiz-Capillas et al. ${ }^{27}$ and Kreyenschmidt et al. ${ }^{28}$, who found that $\mathrm{pH}$ remains constant until the cell concentration of LAB reaches values of approximately $7 \log \mathrm{CFU} / \mathrm{g}$. However, in the studies of Vasilopoulos et al. ${ }^{29}$ and Mataragas et al. ${ }^{30}, \mathrm{pH}$ values decreased when the cell concentration of the LAB was 6 $\log \mathrm{CFU} / \mathrm{g}$ and $8 \log \mathrm{CFU} / \mathrm{g}$, respectively.

As the $\mathrm{pH}$ values of the $\mathrm{LAB}$ begin to decrease with high cell concentrations, this factor cannot be used to characterize shelf life, but it indicates the growth stage of the bacteria, as observed by Dalcanton ${ }^{21}$. 


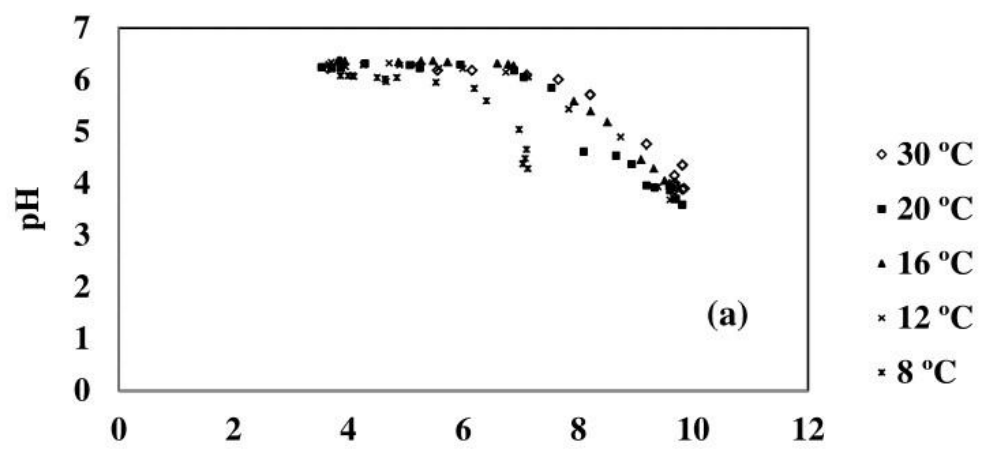

$\log N$

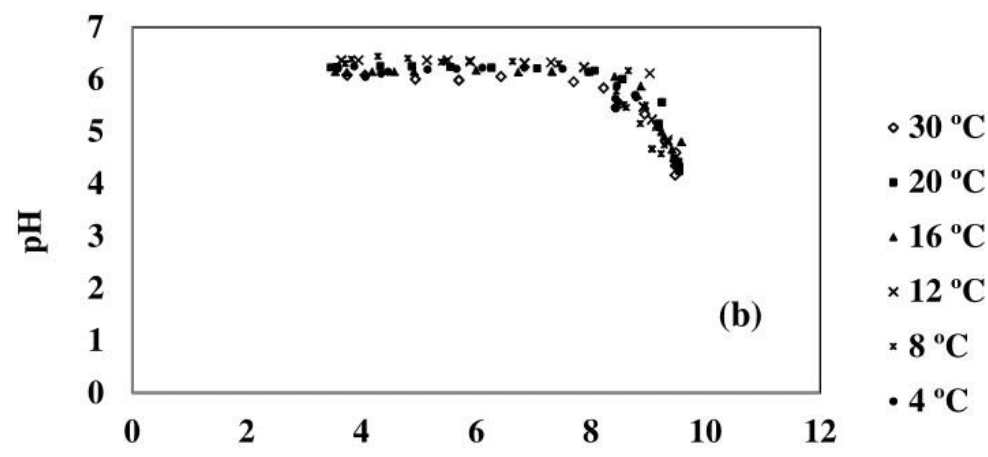

$\log \mathbf{N}$

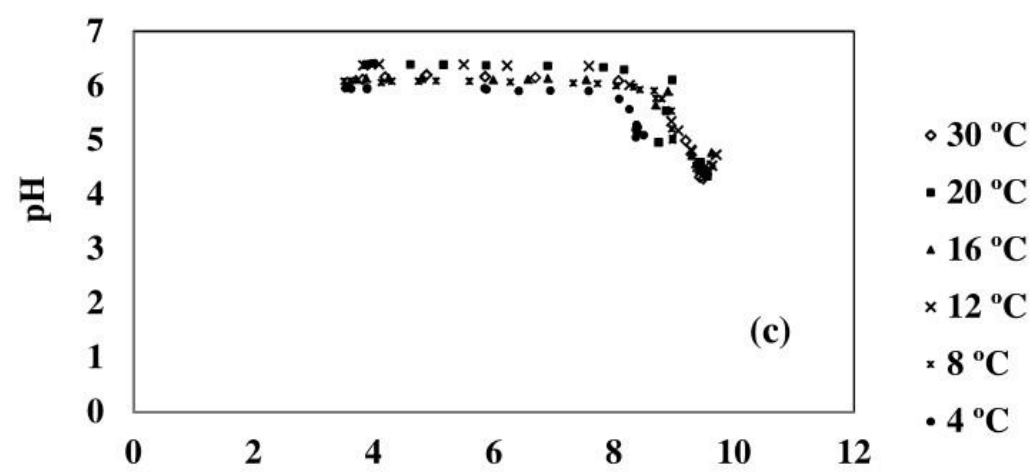

\section{$\log \mathbf{N}$}

Figure 2. Monitoring of pH changes during growth of (a) L. plantarum, (b) W. viridescens and (c) L. sakei at different incubation temperatures.

\section{CONCLUSION}

The both primary models of Baranyi and Roberts and Gompertz showed good fits to the growth curves of $L$. plantarum, W. viridescens and L. sakei, in which the model of Baranyi and Roberts performed slightly better description of the experimental data than the model of Gompertz.

The secondary models allow predicting the growth of the three LAB within the range from $4{ }^{\circ} \mathrm{C}$ to $30{ }^{\circ} \mathrm{C}$. Based on the establishment of both primary and secondary models, it can be concluded that the growth of LAB is strongly influenced by storage temperature, even under refrigerated conditions. 
As seen in this study, the abuse of temperature or the temperature fluctuations that can happen along the cold chain can strongly influence the growth of LAB and, consequently, the shelf life of meat products in which LAB are present.

\section{ACKNOWLEDGEMENTS}

The researchers thank the Graduate Program in Food Engineering of the Federal University of Santa Catarina (UFSC) and CAPES-Brazil for their financial support.

\section{REFERENCES}

1. Slongo AP, Rosenthal A, Camargo LMQ, Deliza R, Mathias SP, Aragão GMF. Modeling the growth of lactic acid bacteria in sliced ham processed by high hydrostatic pressure. LWT - Food Sci Technol. 2009; 42: 303-306.

2. Li MY, Sun XM, Zhao GM, Huang XQ, Zhang JW, Tian W, Zhang QH. Comparison of mathematical models of lactic acid bacteria growth in vacuumpackaged raw beef stored at different temperatures. J Food Sci. 2013; 78: 600-604.

3. Doulgeraki AI, Ercolini D, Villani F, Nychas GJE. Spoilage microbiota associated to the storage of raw meat in different conditions. Int J Food Microbiol. 2012; 157: 130-141.

4. Dalcanton F, Perez-Rodriguez F, Posada-Izquierdo GD, Aragão GMF, GarcíaGimeno RM. Modelling growth of L.plantarum and shelf life of vacuum-packaged cooked chopped pork at different temperatures. Int J Food Sci Tech. 2013; 48: 2580-2587.

5. Cayré ME, Vignolo G, Garro O. Modeling lactic acid bacteria growth in vacuumpackaged cooked meat emulsions stored at three temperatures. Food Microbiol. 2003; 20: 561-566.

6. Nychas G-JE, Skandamis PN, Tassou CC, Koutsoumanis KP. Meat spoilage during distribution. Meat Sci. 2008; 78, 77-89.

7. Samelis J, Kakouri A, Rementzis J. Selective Effect of the product type and the packaging conditions on the species of lactic acid bacteria dominating the spoilage microbial association of cooked meats at $41{ }^{\circ}$ C. Food Microbiol. 2000; 17, 329340.

8. Koutsoumanis KP, Stamatiou AP, Drosinos EH, Nychas GJE. Control of spoilage microorganisms in minced pork by a self-developed modified atmosphere induced by the respiratory activity of meat microflora. Food Microbiol. 2008; 25: 915-921.

9. Giannuzzi L, Pinotti A, Zaritzky N. Mathematical modeling of microbial growth in packaged refrigerated beef at different temperature. Int J Food Microbiol. 1998; 39: 101-110.

10. Manios SG, Lambert RJW, Skandamis PN. A generic model for spoilage of acidic emulsified foods: Combining physicochemical data, diversity and levels of specific spoilage organisms. Int J Food Microbiol. 2014; 170: 1-11.

11. McKellar RC, Lu X. Primary models. In: McKellar RC, Lu X. Modeling Microbial Response in Food. Boca Raton, Florida: CRC PRESS; 2004. p. 33-74.

12. Legan JD. Application of models and other quantitative microbiology tools in predictive microbiology. In: Brul S, Van Gerwen S, Zwietering M. Modelling microorganisms in Food. Cambridge: Woodhead Publishing; 2007. p. 82-109.

13. Gibson AM, Bratchell N, Roberts TA. The effect of sodium chloride and temperature on rate and extent of growth of Clostridium botulinum type A in pasteurized pork slurry. J Appl Bacteriol. 1987; 62: 479-490.

14. Baranyi J, Roberts TA. A dynamic approach to predicting bacterial growth in food. Int J Food Microbiol. 1994; 23: 277-294. 
15. Lobacz A, Kowalik J, Tarczynska A. Modeling the growth of Listeria monocytogenes in mold-ripened cheeses. J Dairy Sci. 2013; 96: 3449-3460.

16. Longhi DA, Dalcanton F, Aragão GMF, Carciofi BAM, Laurindo JB. Assessing the prediction ability of different mathematical models for the growth of Lactobacillus plantarum under non-isothermal conditions. J Theor Biol. 2013; 335: 88-96.

17. Weng PF, Wu ZF, Lei LL. Predictive models for growth of Leuconostoc citreum and its dynamics in pickled vegetables with low salinity. J Food Proc Eng. 2013; 36: 284-291.

18. Ratkowsky DA, Olley J, McMeekin TA, Ball A. Relationship between temperature and growth rate of bacterial cultures. J Bacteriol. 1982; 149: 1-5.

19. Ross T. Indices for performance evaluation of predictive models in food microbiology. J Appl Bacteriol. 1996; 81: 501-508.

20. Baty F, Delignette-Muller ML. Estimating the bacterial lag time: which model, which precision. Int J Food Microbiol. 2004; 91: 261-277.

21. Dalcanton F. Modelagem matemática do crescimento de bactérias ácido lácticas em condições isotérmicas e não isotérmicas. Ph.D. thesis, Federal University of Santa Catarina. Florianópolis, Brasil: 2010. 190 p.

22. Geitenes S, Oliveira MFB, Kalschne DL, Sarmento, CMP. Modelagem do Crescimento de Bactérias Láticas e Análise Microbiológica em Apresuntado e Presunto Cozido Fatiados e Embalados a Vácuo. RECEN. 2013; 15: 113-133.

23. Cayré ME, Garro O, Vignolo G. Effect of storage temperature and gas permeability of packaging film on the growth of lactic acid bacteria and Brochothrix thermosphacta in cooked meat emulsions. Food Microbiol. 2005; 22: 505-512.

24. Pin C, Fernando GDG, Ordóñez JA, Baranyi J. Analysing the lag-growth rate relationship of Yersinia enterocolitica. Int J Food Microbiol. 2002; 73: 197-201.

25. Swinnen IAM, Bernaerts K, Dens EJJ, Geeraerd AH, Van Impe JF. Predictive modelling of the microbial lag phase: a review. Int J Food Microbiol. 2004; 94: 137-159.

26. Costa JCCP. Efeito do tratamento termoquímico (óleo essencial e calor) no crescimento microbiano durante a vida útil de mexilhões (Perna perna) processados em embalagens flexíveis. M.Sc. Dissertation, Federal University of Santa Catarina. Florianópolis, Brasil: 2013. 175 p.

27. Ruiz-Capillas C, Carballo J, Colmenero FJ. Biogenic amines in pressurized vacuum-packed cooked sliced ham under different chilled storage conditions. Meat Sci. 2007; 75: 397-405.

28. Kreyenschmidt J, Hubner A, Beierle E, Chonsch L, Scherer A, Petersen B. Determination of the shelf life of sliced cooked ham based on the growth of lactic acid bacteria in different steps of the chain. J Appl Microbiol. 2010; 108: 510-520.

29. Vasilopoulos C, Ravyths F, Maere H, Mey E, Paelinck H, Vuyst L, Leroy F. Evaluation of the spoilage lactic acid bacteria in modified-atmosphere-packaged artisan-type cooked ham using culture-dependent and culture-independent approaches. J Appl Microbiol. 2008; 104: 1341-1351.

30. Mataragas M, Drosinos EH, Vaidanis A, Metaxopoulos I. Development of a Predictive Model for Spoilage of Cooked Cured Meat Products and Its Validation Under Constant and Dynamic Temperature Storage Conditions. J Food Sci. 2006; 71: 157-167. 